\title{
THE INFLUENCE OF THERMODYNAMIC PARAMETERS ON ALKALINE ACTIVATORS OF GEOPOLYMERS AND THE STRUCTURE OF GEOPOLYMERS
}

\author{
Marija Ivanović $^{1 *}$, Snežana Nenadović1, Vera P. Pavlović ${ }^{2}$ Ivona Radović3 ${ }^{3}$ Mirjana Kijevčanin ${ }^{3}$, \\ Vladimir B. Pavlovićc ${ }^{4}$ Ljiljana Kljajević ${ }^{1^{*}}$ \\ ${ }^{1}$ Department of Materials Science, "Vinča" Institute of Nuclear Sciences - National Institute \\ of the Republic of Serbia, University of Belgrade, Belgrade, Serbia \\ ${ }^{2}$ University of Belgrade, Faculty of Mechanical Engineering, Kraljice Marije 16, 11120 Belgrade, Serbia \\ ${ }^{3}$ University of Belgrade, Faculty of Technology and Metallurgy, Karnegijeva 4, 11120 Belgrade, Serbia \\ ${ }^{4}$ Institute of Technical Sciences of the Serbian Academy of Sciences and Arts, Knez. Mihailova 35/IV, \\ University of Belgrade, 11000 Belgrade, Serbia \\ marija@vinca.rs; 1jiljana@vinca.rs
}

Thermodynamic parameters (densities, viscosities, speed of sound, and refractive index) of four series of alkaline activators were determined over the temperature range from 15 to $60{ }^{\circ} \mathrm{C}$ for the process of geopolymerization. Mixtures of $\mathrm{Na}_{2} \mathrm{SiO}_{3}$ and $\mathrm{NaOH}$ of different molar concentrations (from $2 \mathrm{M}$ to $8 \mathrm{M}$ with step 2) were used as an alkaline activator. The sample with the highest $\mathrm{NaOH}$ concentration also shows the highest values of all thermodynamic parameters. Metakaolin, obtained by calcination of kaolin at $750{ }^{\circ} \mathrm{C}$, was used as the starting material. The samples were characterized by X-ray diffraction (XRD), FTIR and Raman spectroscopy, Scanning Electron Microscopy (SEM), and Energy-Dispersive X-Ray (EDX) Spectroscopy. Results of FTIR analysis correlated with results of Raman Spectroscopy. Due to the polymerization process, the changes in the phonon spectrum were confirmed. The different concentrations of activators do not notably change the $\mathrm{Si} / \mathrm{Al}$ ratio.

Keywords: geopolymer; density; viscosity; speed of sound; refractive index; FTIR; Raman spectroscopy

\section{ВЛИЈАНИЕ НА ТЕРМОДИНАМИЧКИТЕ ПАРАМЕТРИ ВРЗ АЛКАЛНИТЕ АКТИВАТОРИ НА ГЕОПОЛИМЕРИТЕ И СТРУКТУРАТА НА ГЕОПОЛИМЕРИТЕ}

Термодинамичките параметри (густина, вискозитет, брзина на звук и индекс на рефракција) на четири серии алкални активатори беа утврдени во температурниот опсег од 15 до $60{ }^{\circ} \mathrm{C}$ за процесот на геополимеризација. Како алкален активатор се користеа смеси на $\mathrm{Na}_{2} \mathrm{SiO}_{3}$ и $\mathrm{NaOH}$ со различна моларна концентрација (од $2 \mathrm{M}$ до $8 \mathrm{M}$ со чекор 2). Примерокот со најголема концентрација на $\mathrm{NaOH}$ ги покажува и највисоките вредности на сите термодинамички параметри. Како почетен материјал се користеше метакаолин, добиен со калцинација на каолин на $750{ }^{\circ} \mathrm{C}$. Примероците се карактеризираат со дифракција на рендгенски зраци (XRD), FTIR и раманска спектроскопија, скенирачка електронска микроскопија (SEM) и спектроскопија со енергетска дисперзија на рендгенски зраци (EDX). Резултатите од FTIR-анализата беа во корелација со резултатите од раманска спектроскопија. Со процесот на полимеризација беа потврдени промените во фононскиот спектар. Различните концентрации на активаторите не го менуваат особено односот $\mathrm{Si} / \mathrm{Al}$.

Клучни зборови: геополимер; густина; вискозитет; брзина на звук; индекс на рефракција; FTIR; раманска спектроскопија 


\section{INTRODUCTION}

In the past few decades, great technological progress has been achieved with the development of materials such as 'geopolymers' [1]. Techniques for characterizing these materials have also been developed.

Today, the global market and the possibility of its change impose the development of new materials with clean technology in order to reduce the high costs of processing and consumption of natural resources and environmental pollution [2]. Geopolymers are ecological materials obtained through polymerization of aluminosilicates and alkaline solutions. Importantly, there is little greenhouse gas emission during the process of geopolymerization [3, 4]. The geopolymerization process is complex. Geopolymers are commonly obtained at low temperatures (under $100{ }^{\circ} \mathrm{C}$ ) by mixing different kinds of aluminosilicate materials with an alkali hydroxide or alkali silicate solution [5-7]. The amorphous geopolymer network is composed of an interchangeable series of tetrahedral $\left[\mathrm{SiO}_{4}\right]$ and $\left[\mathrm{AlO}_{4}\right]$ molecules, and the microstructure is composed of nanoparticulates separated by micro- and meso-pores [8,9]. Futhermore, geopolymers can be considered to be amorphous precursors of crystalline zeolites $[6,10]$.

Geopolymers are characterized by their low cost and simple production process which does not pollute the environment. Due to the simple production process, it is very easy to shape the final product [6]. As for the alkaline activator itself, it's most relevant properties are viscosity and heat of dissolution [11]. Thermodynamic properties of the mixture derived from measuring density, viscosity, and speed of sound contribute to easier design of engineering processes.

The aim of this research was to examine the influence of the different concentrations of alkaline activator on the geopolymerization process and the structure of geopolymer samples obtained. In order to accomplish this, analyses of the XRD, FTIR, and Raman spectra as well as SEM/EDS analyses of geopolymers were performed. Also, the effect of temperature on the density, viscosity, velocity of sound, and refractive index of the alkali activators (liquid phase) (2MAA, 4MAA, 6MAA and 8MAA) was analyzed prior to the geopolymerization itself.

\section{MATERIALS AND METHODS}

Geopolymers $(\mathrm{G})$ were synthesized from a metakaolin precursor and a source of aluminosili- cate species. Metakaolin is obtained from the process of thermal treatment of kaolinite (Rudovci, Serbia). As far as metakaolin is concerned, the thermal treatment of kaolin at $750{ }^{\circ} \mathrm{C}$ with heating rate of $10 \% \mathrm{~min}$ and soaking time of one hour at elevated temperature causes transformations which develop through three principal mechanisms: a) dehydroxylation of kaolinite with the subsequent partial destruction of the original lamellae of this mineral and a partial change of the coordination number of aluminum ions from six to five and four b) aggregation of the particles of metakaolinite, which determines the formation of drastically bigger porous granules; and c) beginning of the sintering of the granules, which mainly depends on the temperature reached during the thermal treatment. The main effect of this process is a decrease in the specific surface area [12].

The some parts of the procedure for geopolymer synthesis was described in our previous studies $[13,14]$. To equilibrate the activator, it is held at room temperature for one day prior to preparation of geopolymer materials.

In the experiment, water glass i.e. sodium silicate $\left(\mathrm{Na}_{2} \mathrm{SiO}_{3}\right)$ and sodium hydroxide $(\mathrm{NaOH})$, were used as alkaline activators. Water glass manufactured by Galenika-Magmasil, Serbia, has 14.3 $\% \mathrm{Na}_{2} \mathrm{O}$ and $28.2 \% \mathrm{SiO}_{2}$, and density (at $20{ }^{\circ} \mathrm{C}$ ) $\rho$ $=1.51 \mathrm{~g} / \mathrm{cm}^{3}$. In order to analyze the influence of the concentration of sodium hydroxide solution (Sigma-Aldrich) on the structural and morphological properties of the geopolymer sample, we prepared a sample with the solid to liquid phase ratio of 0.75 . Compared to the previously mentioned syntheses [13], this has a slightly higher liquid phase content $\left(\mathrm{Na}_{2} \mathrm{SiO}_{3} / \mathrm{NaOH} / \mathrm{H}_{2} \mathrm{O}\right)$, and better homogenization of the samples was achieved with constantly shaking the mix of the solid and liquid phase for the first six hours after synthesis. Four series of alkaline activators were used. Alkaline activators marked as 2MAA, 4MAA, 6MAA and 8MAA were mixtures with a determined volume of $\mathrm{Na}_{2} \mathrm{SiO}_{3}$ and solutions of $\mathrm{NaOH}$ with different molarities of $2 \mathrm{~mol} / \mathrm{dm}^{3}, 4 \mathrm{~mol} / \mathrm{dm}^{3}, 6 \mathrm{~mol} / \mathrm{dm}^{3}$ and 8 $\mathrm{mol} / \mathrm{dm}^{3}$, respectively ( $\mathrm{M}$ is the molar mass over which the concentration of sodium hydroxide solution is presented). The geopolymer samples obtained were marked as $2 \mathrm{MG}, 4 \mathrm{MG}, 6 \mathrm{MG}$ and $8 \mathrm{MG}$.

Density as well as sound speed were measured on an Anton Paar DSA 5000 M digital gauge with a $U$ tube (with built-in automatic viscosity correction) with a repeatability of $\pm 1 \cdot 10^{-3} \mathrm{~kg} \cdot \mathrm{m}^{-3}$ for the density, $\pm 0.1 \mathrm{~m} \cdot \mathrm{s}^{-1}$ for the speed of sound, and $\pm 0.001 \mathrm{~K}$ for the temperature. The density 
measurement range on this instrument is 0 to $3 \cdot 10^{-3}$ $\mathrm{kg} \cdot \mathrm{m}^{-3}$, while the sound speed range is 1000 to $2000 \mathrm{~m} \cdot \mathrm{s}^{-1}$. All of the measurements were made in the temperature range from $288.15 \mathrm{~K}$ to $333.15 \mathrm{~K}$. Calibration of the apparatus was performed daily with the help of air and Millipore water.

The refractive index $n_{\mathrm{D}}$ was measured on an automatic refractometer (Anton Paar RXA model 156) operating at a wavelength of $589 \mathrm{~nm}$. During the measurement, the sample temperature was maintained constant using a built-in thermostat with an accuracy of $\pm 0.03 \mathrm{~K}$. The refractive index measurement range is 1.32 to 1.56 . The calibration of the apparatus was performed daily using Millipore water.

Viscosity $\eta$ was measured on a digital Stabinger viscometer (model SVM 3000 / G2). This instrument contains two measuring cells. One measures the density of the sample while the other measures dynamic viscosity. Repeatability of dynamic viscosity and density measurements was $0.35 \%$ and $\pm 0.5 \mathrm{~kg} \cdot \mathrm{m}^{-3}$, respectively. During the procedure, the measured temperature in the cell is regulated to $\pm 0.01 \mathrm{~K}$ using a built-in thermostat. The viscosity measurement range is 0.2 to 20,000 $\mathrm{mPa} \cdot \mathrm{s}$. The apparatus was completely washed with an appropriate solvent before inserting the sample and starting to measure densities, sound velocities and refractive index. The procedure was repeated after each measurement and before inserting a new sample.

The investigation of the physical and structural characteristics of the geopolymer materials (2MG, 4MG, 6MG, 8MG) requires the implementation of several techniques. All samples were characterized by X-ray diffractometry (XRD) by using an Ultima IV Rigaku diffractometer; the $2 \theta$ range $5^{\circ}$ to $80^{\circ}$ was used for all powders; scan rate was $5 \%$ min. FTIR spectra were taken at room temperature using a Bomem (Hartmann \& Braun) MB-100 spectrometer.

Raman spectroscopy of MK and geopolymer samples was performed in the 200-1200 $\mathrm{cm}^{-1}$ range on a LabRAM HR Evolution system by using $532 \mathrm{~nm}$ laser line. All of the measurements were realized using a spectrometer equipped with a grating having 1800 lines $/ \mathrm{mm}$ and a $100 \times$ microscope objectives. Power at the sample was $25 \mathrm{~mW}$, and the acquisition integration time was $60 \mathrm{~s} / 4 \mathrm{cy}$ cles. SEM and EDS spectroscopy was performed for all Au-coated samples using a JEOL JSM 6390 $\mathrm{LV}$ electron microscope at $25 \mathrm{kV}$.

\section{RESULTS AND DISCUSSION}

\subsection{Thermodynamic parameters of alkaline activator solutions}

The densities, viscosities, speed of sound, and refractive index of alkaline activators were determined at the temperature range from 15 to 60 ${ }^{\circ} \mathrm{C}$. This temperature range covers the process of geopolymerization. In the Figures 1, 2, 3 and 4, we can see the dependence of the mentioned thermodynamic parameters of the alkaline activators on temperature.

Figure 1 shows the effects of temperature on the density of different prepared alkali activators which will be used in the process of alkali activation of metakaolin.

Figure 2 shows the effects of temperature on the refractive index of different prepared alkali activators which will be used in process of alkali activation of metakaolin.

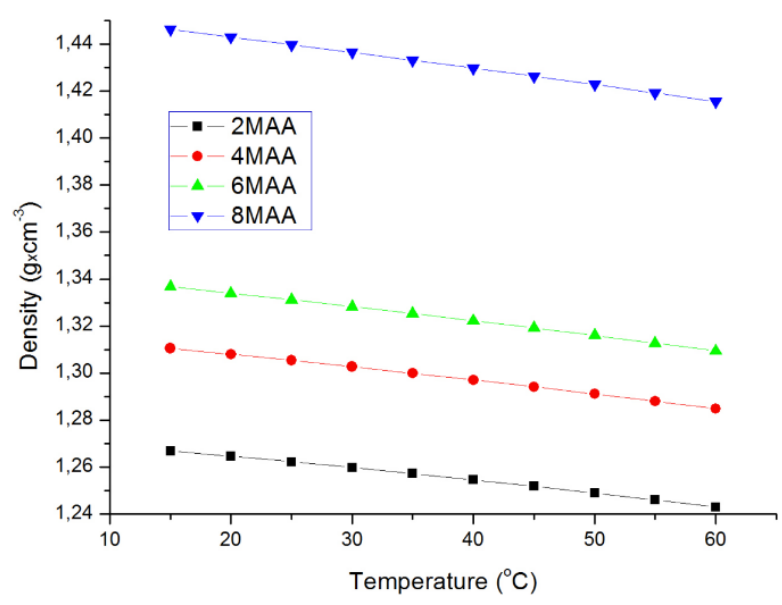

Fig. 1. Effect of temperature on the density of alkali activators

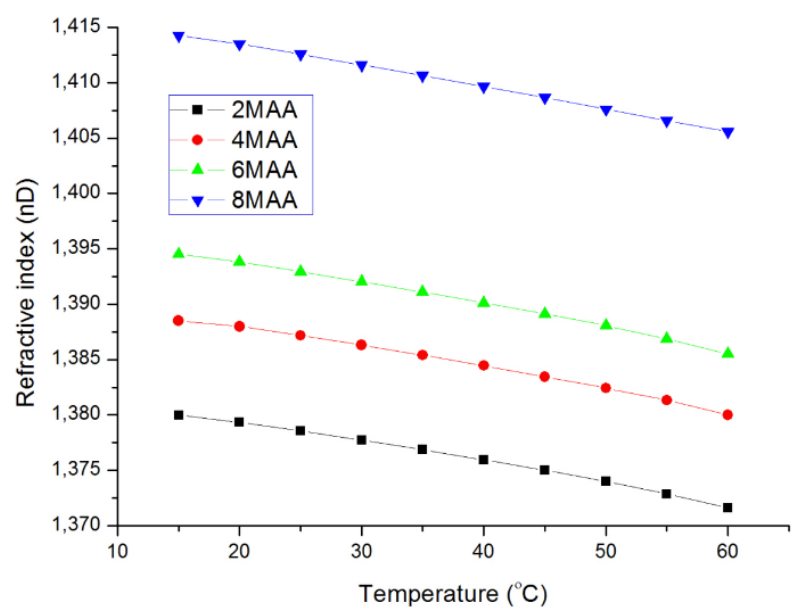

Fig. 2. Effect of temperature on the refractive index of alkali activators 
Changes in density (Fig. 1) and the temperature-dependent refractive index (Fig. 2) for all alkali activators systems followed the usual behavior observed in liquid systems. The values of the mentioned parameters decrease with increasing temperature due to the thermal expansion of the liquid. This behavior can be attributed to a decrease in the intermolecular forces in a liquid caused by the thermal expansion of the liquid and an increase in the velocities of the molecules (or ions) at higher temperatures.

Figure 3 shows the effects of temperature on the viscosity of different prepared alkali activators which will be used in process of alkali activation of metakaolin.

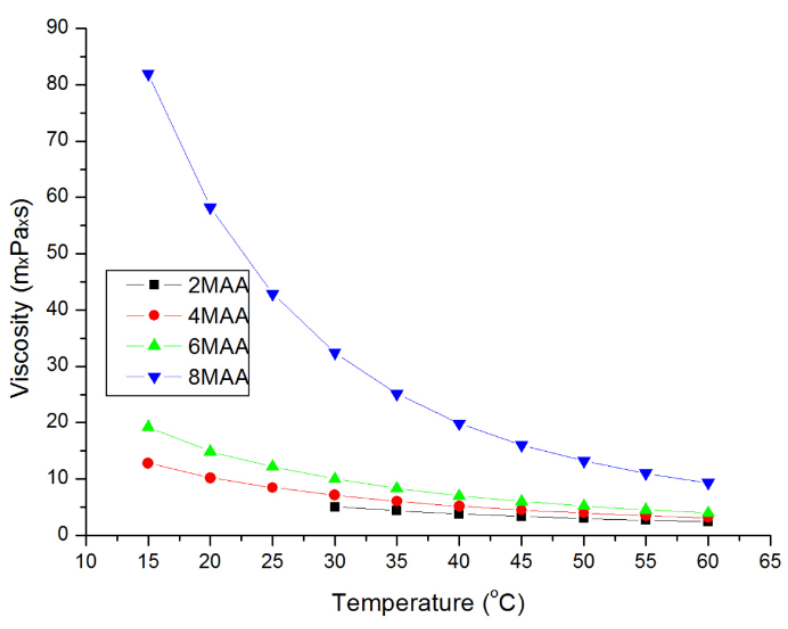

Fig. 3. Effect of temperature on the viscosity of alkali activators

The graphs clearly show that the values of all parameters increase with increasing the molarity of the alkaline activator. The most pronounced effect was observed with viscosity (Fig 3). The system with the highest molarity 8MAA shows more than four times higher viscosity compared to the other three analyzed systems, especially at lower temperatures. As the temperature rises, the viscosity of the sodium silicate solution decreases significantly, falling by a factor of about eight after heating from $20{ }^{\circ} \mathrm{C}$ to $40{ }^{\circ} \mathrm{C}$. After this point, the viscosity values continue to decrease without a significant drop [15]. At elevated temperatures, the solubility of some sodium metasilicate phases decreases, which shows us that heating is not a guaranteed way to ensure or accelerate the dissolution of solid precursors during the preparation of the geopolymer activation solution. One of Vail's assumptions [16] is that the viscosity behavior of mixed alkaline silicates is relatively complex. Some mixed alkali solutions with high silicon di- oxide content show much higher viscosity than any of the pure alkaline solutions [16]. The viscosity of sodium silicate solution above a relatively wide concentration range does not depend on the shear rate even at high $\mathrm{SiO}_{2} / \mathrm{Na}_{2} \mathrm{O}$ ratios $[15,16]$.

Figure 4 shows the effects of temperature on the speed of sound of different prepared alkali activators which will be used in process of alkali activation of metakaolin.

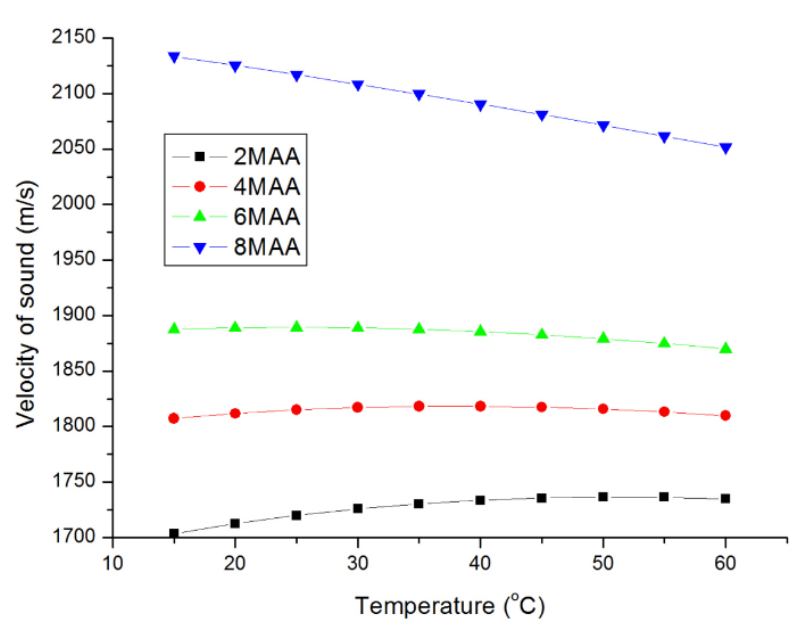

Fig. 4. Effect of temperature on the speed of sounds of alkali activators

As for the value of the speed of sound (Fig 4), a small increase is observed with increasing temperature in solutions of 2MAA, 4MAA and 6MAA, which can be an indicator of increased ion mobility in solution. Knowing the values of the density and viscosity of a silicate solution at a given temperature may be sufficient to calculate its composition without chemical analysis because these properties can be reliably and repeatedly measured even for metastable solutions [16]. These systems have been shown to behave like conventional liquid systems; that is, they decrease with increasing temperature due to thermal expansion of the liquid. The proposal of appropriate correlations which could be used to calculate the measured values as a function of temperature of the tested systems for their further use in other applications could be an additional goal of this paper.

\subsection{Characterization of metakaolin and geopolymer samples}

\subsubsection{Raman and FTIR analysis}

The results of Raman spectroscopy of MK and geopolymer samples are reported in Figure 5. The most intense peak in the MK powder appears 
at $\sim 264 \mathrm{~cm}^{-1}$. According to the literature data, the position of this peak could be assigned to the strongest in-plane deformation vibrational mode $\mathrm{O}-\mathrm{Si}-\mathrm{O}$ in the muscovite [17]. The peaks at $\sim 400$ $\mathrm{cm}^{-1}$ and $519 \mathrm{~cm}^{-1}$ originate from the bending modes of $\mathrm{Si}-\mathrm{O}-\mathrm{Al}$ and $\mathrm{Si}-\mathrm{O}-\mathrm{Si}$, respectively [18]. A peak at $790-810 \mathrm{~cm}^{-1}$ is also observed. This peak includes the bands at 790 and $802 \mathrm{~cm}^{-1}$ which can be attributed to Al-O bonds in $\mathrm{Al}_{2} \mathrm{O}_{3}$ [19] and to $\mathrm{Si}-\mathrm{O}-\mathrm{Si}$ bending symmetric modes in the $\mathrm{MK}$ $[20,21]$. A wide peak at $930-1010 \mathrm{~cm}^{-1}$ results from the bands that correspond to the stretching vibrations of $\mathrm{Si}-\mathrm{O}$ bonds in $\mathrm{SiO}_{2}$ [19].

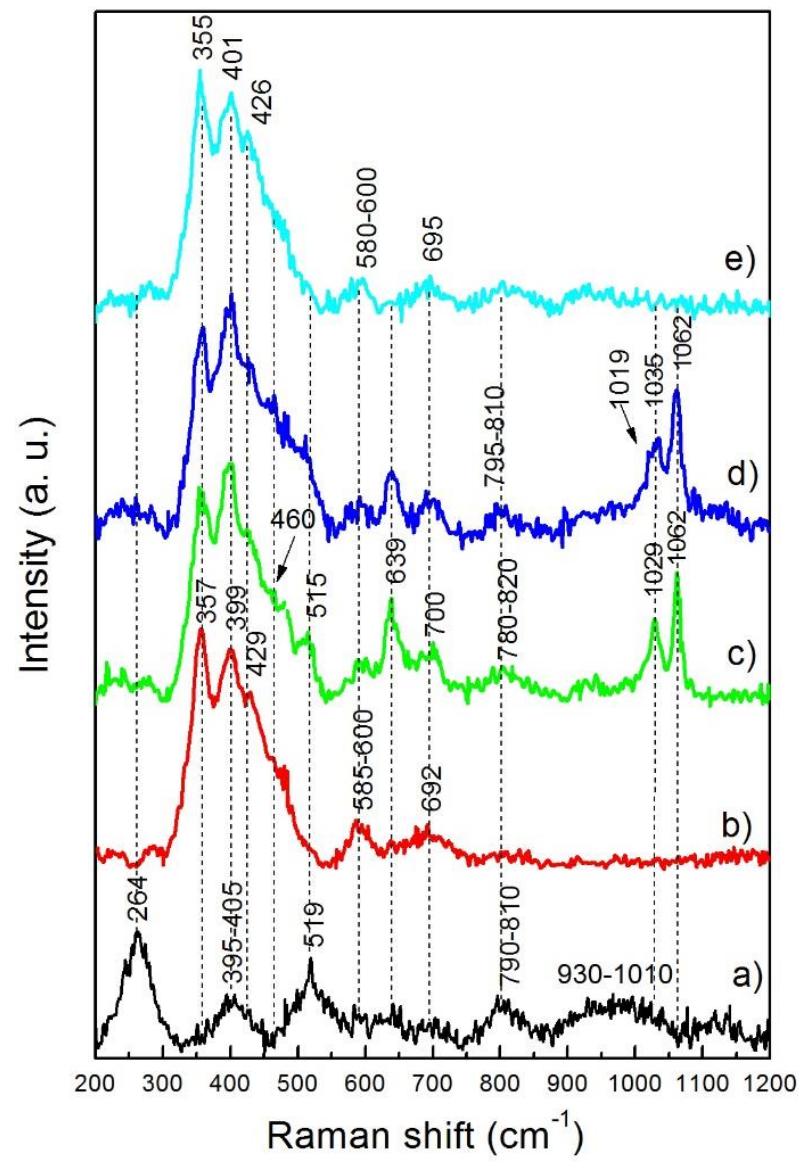

Fig. 5. Raman spectra of metakaolin and geopolymer samples: a) $\mathrm{MK}$; b) $2 \mathrm{MG}$; c) $4 \mathrm{MG}$; d) $6 \mathrm{MG}$; e) $8 \mathrm{MG}$

As shown in Figure 5, Raman spectra of geopolymer samples significantly differ from the spectrum of metakaolin. In the $2 \mathrm{MG}$, the main Raman spectra peaks are located at $357 \mathrm{~cm}^{-1}$ and $399 \mathrm{~cm}^{-1}$, where the second peak corresponds to the bending modes of Si-O-Al [18]. Although the first peak can originate from the Si-O and/or Al-O vibrations, the $\mathrm{Na}-\mathrm{O}$ modes contribute to it as well [22]. The shoulder at $\sim 429 \mathrm{~cm}^{-1}$ can be induced by Si-O symmetric ring-breathing vibrations in 5-fold or more-fold planar rings. However, some of the authors have assigned this peak to the asymmetric bending modes [20]. The peak at $585-600 \mathrm{~cm}^{-1}$ can be associated not only to the deformation of the bridging oxygen (BO) bonds in $\mathrm{X}-\mathrm{O}-\mathrm{X}(\mathrm{X}: \mathrm{Si}$ or $\mathrm{Al}$ ) and to a rocking motion of $\mathrm{BO}$ in structural units that contain nonbridging oxygen (e.g., in structural units with $\mathrm{NBO} / \mathrm{X}=1$ ) [25], but also partly to the ring-breathing mode of threemembered rings, $\mathrm{D}_{2}\left(\delta\left[\mathrm{R}_{3}\right]\right)[20,23]$. In some of the geopolymer samples (4MG and 6MG), a decrease of the last mentioned peak was noticed, followed by the occurrence of the strong peak at $639 \mathrm{~cm}^{-1}$. It is assumed that peak at $639 \mathrm{~cm}^{-1}$ corresponds to the symmetric stretching modes of $\mathrm{X}-\mathrm{O}$ (X: $\mathrm{Si}$ or $\mathrm{Al}$ ) bonds [18]. In the $4 \mathrm{MG}$ and $6 \mathrm{MG}$ samples, changes in intensity ratio of the strongest peaks (in the $350-405 \mathrm{~cm}^{-1}$ region) were also recorded as well as an enhancement of the peaks at $\sim 700 \mathrm{~cm}^{-1}$ and $780-820 \mathrm{~cm}^{-1}$. In the literature, it is often mentioned that the rage of $700-900 \mathrm{~cm}^{-1}$ corresponds to symmetric $\mathrm{Si}-\mathrm{O}$ or Al-O stretching modes [18, 26]. Furthermore, it is indicated that the peak at $\sim 700 \mathrm{~cm}^{-1}$ can dominantly correspond to the contribution of 4-membered rings. It should be noticed that the peak which covers the bands at 790 and $802 \mathrm{~cm}^{-1}$ can be primarily attributed to $\mathrm{Si}-\mathrm{O}-\mathrm{Si}$ bending symmetric modes in geopolymers [20, 21]. Some authors [27] pointed out that a peak at $780 \mathrm{~cm}^{-1}$ originates from the vibrations of $\mathrm{Si}-\mathrm{O}-\mathrm{Si}$ network and $\mathrm{AlO}_{4}$ units with three bridging oxygens (BO) and one nonbridging oxygen (NBO). In addition, modes corresponding to the $\mathrm{Si}-\mathrm{OH}$ stretching vibration of $\mathrm{SiO}(\mathrm{OH})_{3}{ }^{-}$can also contribute to this peak [28]. On the other hand, it is possible that the peak at $780-820 \mathrm{~cm}^{-1}$ partly corresponds to Al-O bonds in $\mathrm{Al}_{2} \mathrm{O}_{3}$ within the residual MK [19]. The weak peak at $\sim 515 \mathrm{~cm}^{-1}$ also indicates some residual amount of $\mathrm{MK}$ in the $4 \mathrm{MG}$ and $6 \mathrm{MG}$ samples. The shoulder at $460-470 \mathrm{~cm}^{-1}$ that is detectable in the geopolymer samples could be related to the position of the strongest $\alpha$-quartz mode, which is usually assigned to the symmetric stretching $\mathrm{Si}-\mathrm{O}-\mathrm{Si}$ vibrations within the $\mathrm{SiO}_{4}$ tetrahedron. However, the occurrence of two strong peaks in the range $1019-1060 \mathrm{~cm}^{-1}$, which is observed in the samples $4 \mathrm{MG}$ and $6 \mathrm{MG}$, is not detected in the MK sample or in the GP2M and GP8M samples. The first peak, observed at about $1030 \mathrm{~cm}^{-1}$ in $4 \mathrm{MG}$, is attributed to Si-O-stretching vibrations $\left(v \mathrm{O}^{-} \mathrm{SiO}^{-}\right)$ [28]. The second peak, located at $1062 \mathrm{~cm}^{-1}$, belongs to the area that includes asymmetric stretching modes X-O (X: Si or Al) as in zeolites [18, 20, 25]. That peak can also be related to the contribution of the $\mathrm{Q}_{3}$ polymerization type such as $v_{\mathrm{s}}\left(\mathrm{Si}-\mathrm{O}^{-}\right)\left(\mathrm{Q}_{3}\right)$, 
where index 3 refers to the number of bridging oxygens (BO) per tetrahedron [22, 23, 29].

Figure 6 shows the FTIR spectra of the geopolymers $(2 \mathrm{MG}, 4 \mathrm{MG}, 6 \mathrm{MG}$ and $8 \mathrm{MG})$ that have been aged for 28 days at room temperature. The strong peaks at $3450 \mathrm{~cm}^{-1}$ and $1640 \mathrm{~cm}^{-1}$ originate from $\mathrm{OH}$ valence and $\mathrm{HOH}$ deformation vibrations of adsorbed water. With increasing molarities, the intensity of the band at $3450 \mathrm{~cm}^{-1}$ increases. Small peaks at $2922 \mathrm{~cm}^{-1}$ and $2849 \mathrm{~cm}^{-1}$ occur due to organic impurities of $\mathrm{C}-\mathrm{H}$ vibrations.

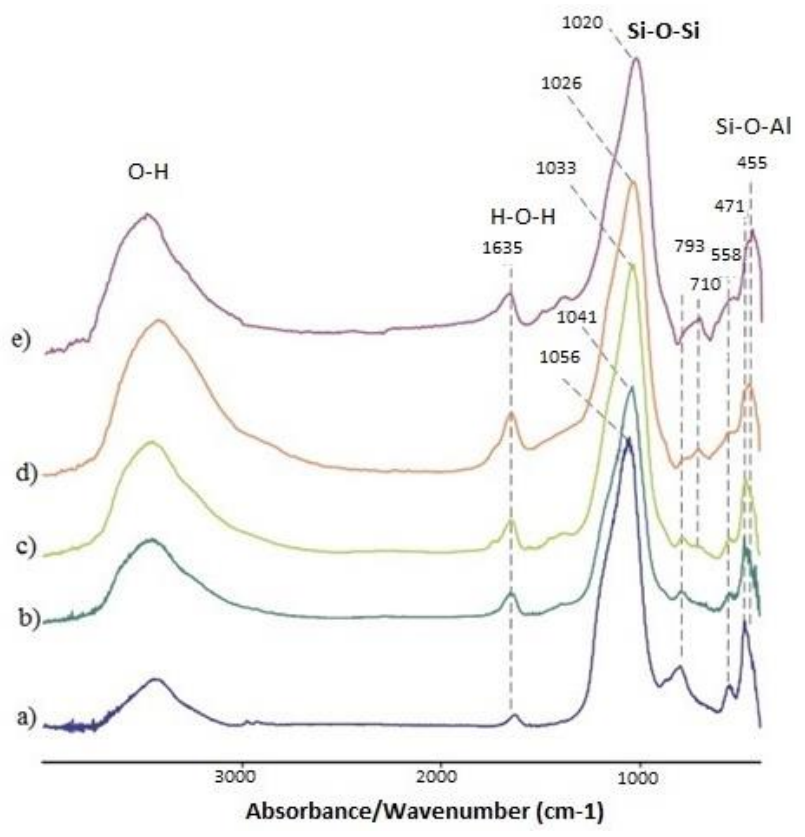

Fig. 6 FTIR spectra of metakaolin and geopolymer samples after aging twenty eight days at room temperature: a) $\mathrm{MK}$; b) $2 \mathrm{MG}$; c) $4 \mathrm{MG}$; d) $6 \mathrm{MG}$; e) $8 \mathrm{MG}$

The bands located at $1100 \mathrm{~cm}^{-1}$ and 1000 $\mathrm{cm}^{-1}$ that belong to the stretching of the $\mathrm{Si}-\mathrm{O}$ bonds are shifted to the right. The form of these bands changes due to structural arrangements within the geopolymer, which are induced by changing the concentration of the $\mathrm{NaOH}$ in activator solutions. The broadening of these bands is more notable when using $8 \mathrm{M} \mathrm{NaOH}$. The FTIR $\mathrm{Si}-\mathrm{O}$ bending bands are found at $800 \mathrm{~cm}^{-1}$ and between 890 $\mathrm{cm}^{-1}$ and $975 \mathrm{~cm}^{-1}$. The band at approximately $1050 \mathrm{~cm}^{-1}$ is assigned to the $\mathrm{Si}-\mathrm{O}$ stretching of tetrahedrons in which silicon is surrounded by three bridging oxygen units and one non-bridging oxygen [30-32]. This structure is the building block of the $\mathrm{Si}-\mathrm{O}-\mathrm{X}(\mathrm{X}=\mathrm{Si}, \mathrm{H}, \mathrm{O})$ geopolymer. A shift of the $\mathrm{Si}-\mathrm{O}-\mathrm{X}$ stretching band towards lower wave numbers shows lengthening of $\mathrm{Na}$ or $\mathrm{H}$ bonds and shrinkage in the bond angle [33]. This shift can be also attributed to an increase of the fraction of silicon sites with non-bridging oxygen atoms [34]. FTIR spectra of our geopolymer materials show a shift of the $\mathrm{Si}-\mathrm{O}-\mathrm{X}$ stretching band: its position is $1056 \mathrm{~cm}^{-1}(\mathrm{MK}), 1041 \mathrm{~cm}^{-1}$ (2MG), $1033 \mathrm{~cm}^{-1}$ (4MG), $1026 \mathrm{~cm}^{-1}$ (6MG), and 1020 $\mathrm{cm}^{-1}$ (8MG). The peak at $710 \mathrm{~cm}^{-1}$ in the FTIR spectra of geopolymer samples (for the molarity above $2 \mathrm{M}$ ) could indicate an asymmetric $\mathrm{Si}-\mathrm{O}-\mathrm{Al}$ bond [33]. The intensity of the peak at $710 \mathrm{~cm}^{-1}$ increases with the rise of $\mathrm{NaOH}$ concentration. These changes indicate that there are fine changes in the aluminosilicate structure as the geopolymer synthesis progresses with increasing alkaline activator concentrations. The presence of quartz was evidenced by the Si-O-Si vibrations from quartz at $793 \mathrm{~cm}^{-1}$, which confirmed that the quartz impurity was stable, independent of the heat-treatment temperature. Also, according to some authors, the range of $800-550 \mathrm{~cm}^{-1}$ includes the bands that correspond to the vibrational connections of the secondary building units (SBUs). SBUs are formed by joining $\mathrm{SiO}_{4}$ and an $\mathrm{AlO}_{4}$ tetrahedron, whereby numerous rings are formed. This area is a fingerprint of the geopolymer structure. This type of addiction was not observed for the samples $2 \mathrm{MG}$ and 4MG. Besides, the peak that occurs in the MK at $471 \mathrm{~cm}^{-1}$ moved to the lower value of $455 \mathrm{~cm}^{-1}$ for the $6 \mathrm{MG}$ and $8 \mathrm{MG}$ samples.

If we look at the end of the process $\left(28^{\text {th }}\right.$ day) we can clearly see the influence of molarity. The peak that occurs at $1041 \mathrm{~cm}^{-1}$ for the sample $2 \mathrm{MG}$ moved to the position at $1020 \mathrm{~cm}^{-1}$ for the sample $8 \mathrm{MG}$. With increasing the molarity of $\mathrm{NaOH}$, the intensity of the band at $793 \mathrm{~cm}^{-1}$ decreases with respect to the intensity of the band at $710 \mathrm{~cm}^{-1}$.

\subsection{2. $X R D$ and SEM/EDS analysis}

MK and 2MG, 4MG, 6MG, and 8MG samples were analyzed by XRD in order to investigate changes in all of the samples' mineralogical structure. Figure 7 shows the XRD patterns of MK and the XRD patterns of powdered geopolymer samples aged for twenty eight days.

Due to the structural difference of the amorphous phase in metakaolin and geopolymer samples, the aluminosilicate broad humps appear in different positions (metakaolin, $\sim 15-35^{\circ} 2 \theta$; geopolymer samples, $\sim 12^{\circ}-38^{\circ} 2 \theta$ ). The centers of the broad humps shift to a higher angle, and the hump of geopolymer samples is broadened after geopolymerization, which indicates the new structure of amorphous phase [35]. 


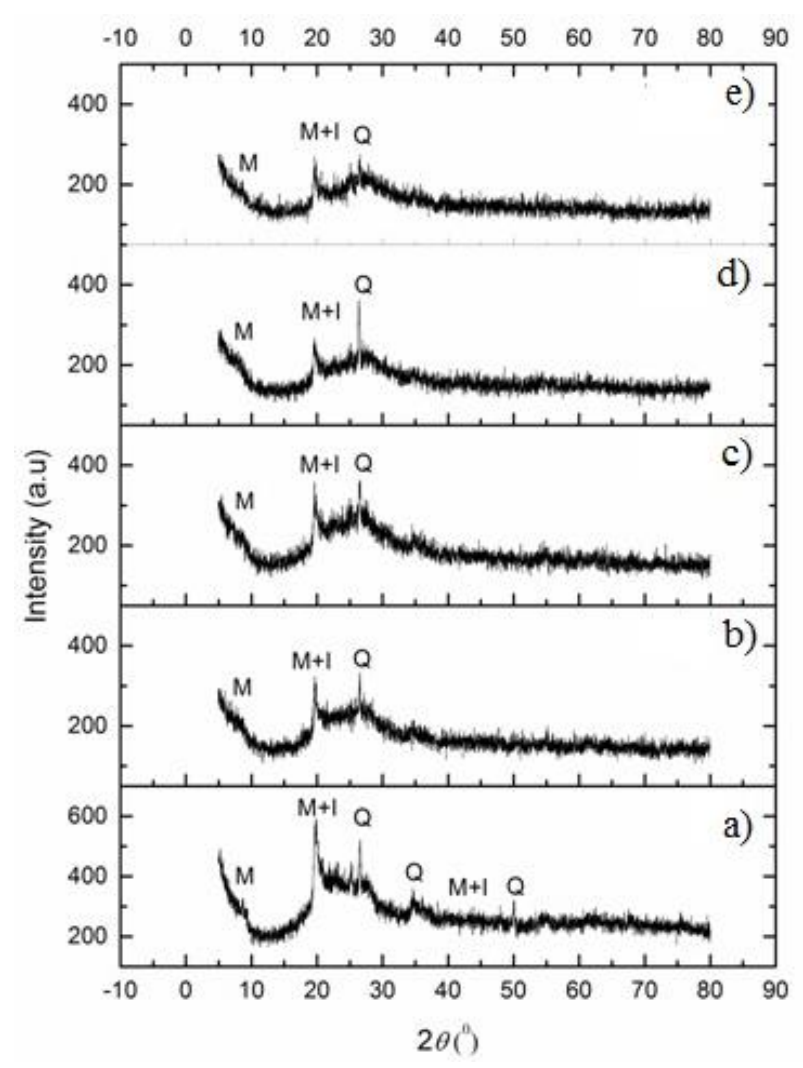

Fig. 7. XRDP of metakaolin and geopolymer samples after twenty eight days aging at room temperature: a) $\mathrm{MK}$; b) $2 \mathrm{MG}$; c) $4 \mathrm{MG}$; d) $6 \mathrm{MG}$; e) $8 \mathrm{MG}$

XRD analysis of metakaolin and all geopolymer samples revealed their amorphous-like structure, which indicates short range ordering of all samples with crystalline phases of $\mathrm{SiO}_{2}(\alpha$-quartz, ICSD 89), muscovite and illite. After the process of alkali activation of aluminosilicates, several authors [36-39] observed the formation of new semicrystalline and crystalline phases. In our case, no new crystalline phases were formed. The fact that the part of the diffractogram indicating the presence of the amorphous phase has shifted to a wider range shows that there have been structural rearrangements in the amorphous phase. Regarding the changes in the amorphous part of the geopolymer samples, no large differences were observed based on XRD analysis.

The SEM analysis was employed to investigate the morphology of powdered geopolymer samples and metakaolin samples. Figure 8 shows the SEM images and the EDS spectra of metakaolin, while Figure 9 shows SEM micrographs and EDS spectra of geopolymer samples.

The presence of quartz and other impurities is noticeable on SEM micrographs (Fig. 8). On the surface of lamellar porous MK aggregates, tiny crystalline particles smaller than $2 \mu \mathrm{m}$ can be observed.

The geopolymer samples show a microstructure of unreacted micron sized particles and a geopolymeric matrix that were formed during the polycondensation. The presence of quartz and the other crystal particles as impurities is more noticeable in geopolymer samples. The accumulation of impurity particles, which includes the present crystalline phases that were detected by XRD analysis, is most pronounced in the $2 \mathrm{MG}$ sample. This is a consequence of the least amount of geopolymer gel created as an amorphous phase, due to the lowest molarity of the alkaline activator. They are seen as clusters of these particles arranged on the surface of an amorphous gel which is of a very different shape. These particles did not participate in the geopolymerization process. Quartz is usually detected as an impurity of kaolinite clays. At first view, the microstructures of all the geopolymer samples obtained seem to be similar.
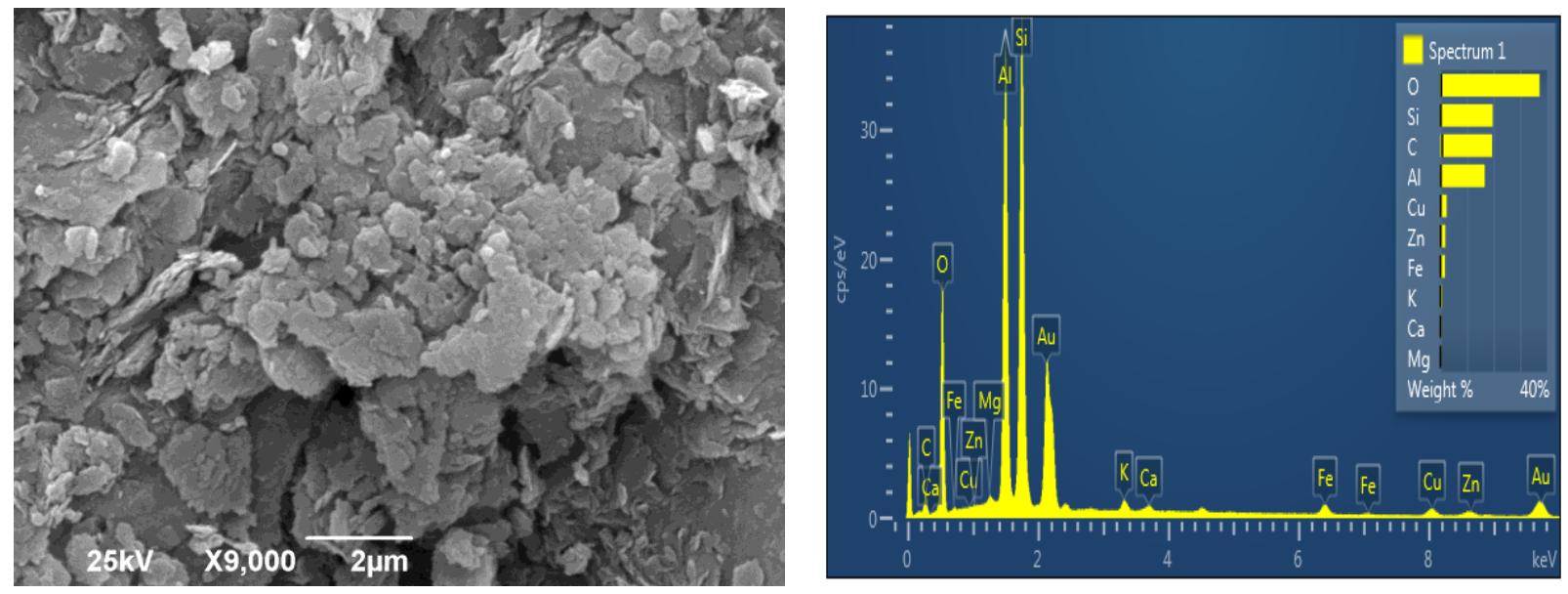

Fig. 8. SEM micrographs of metaphase of kaolin-metakaolin 

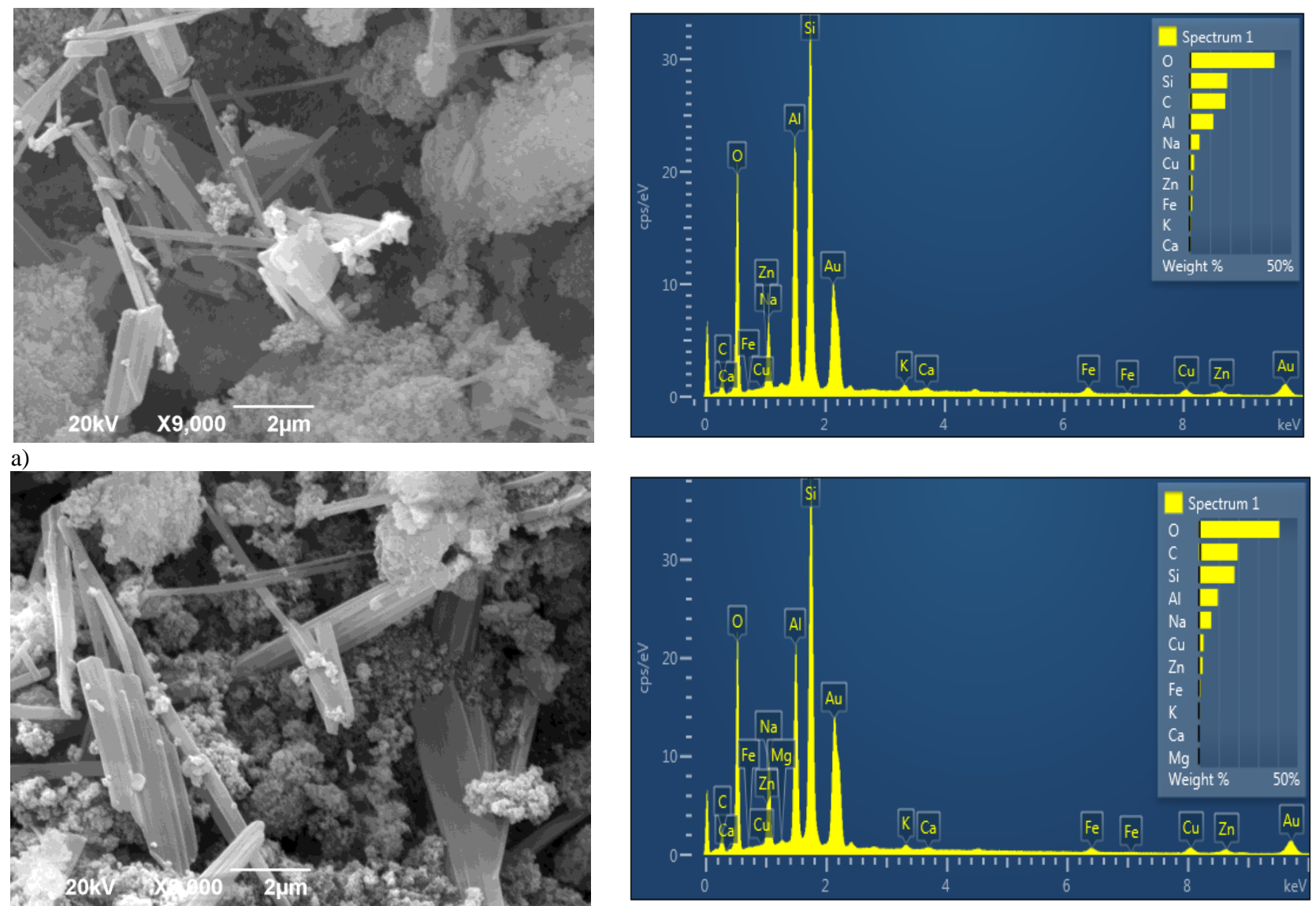

b)
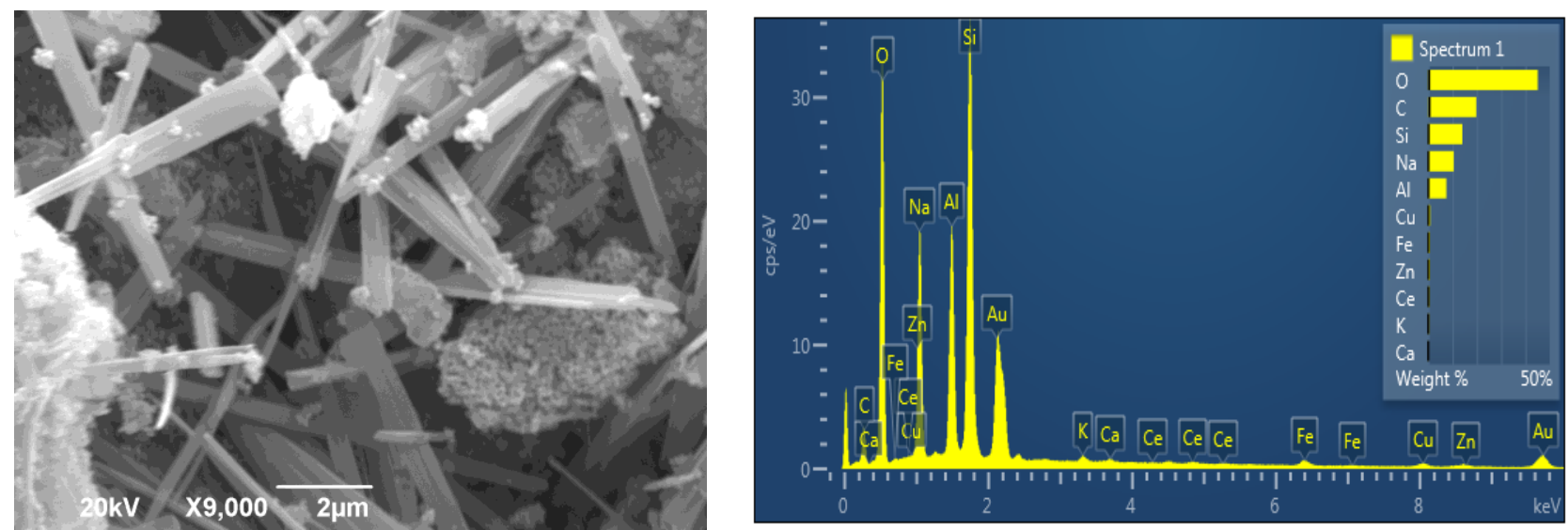

c)
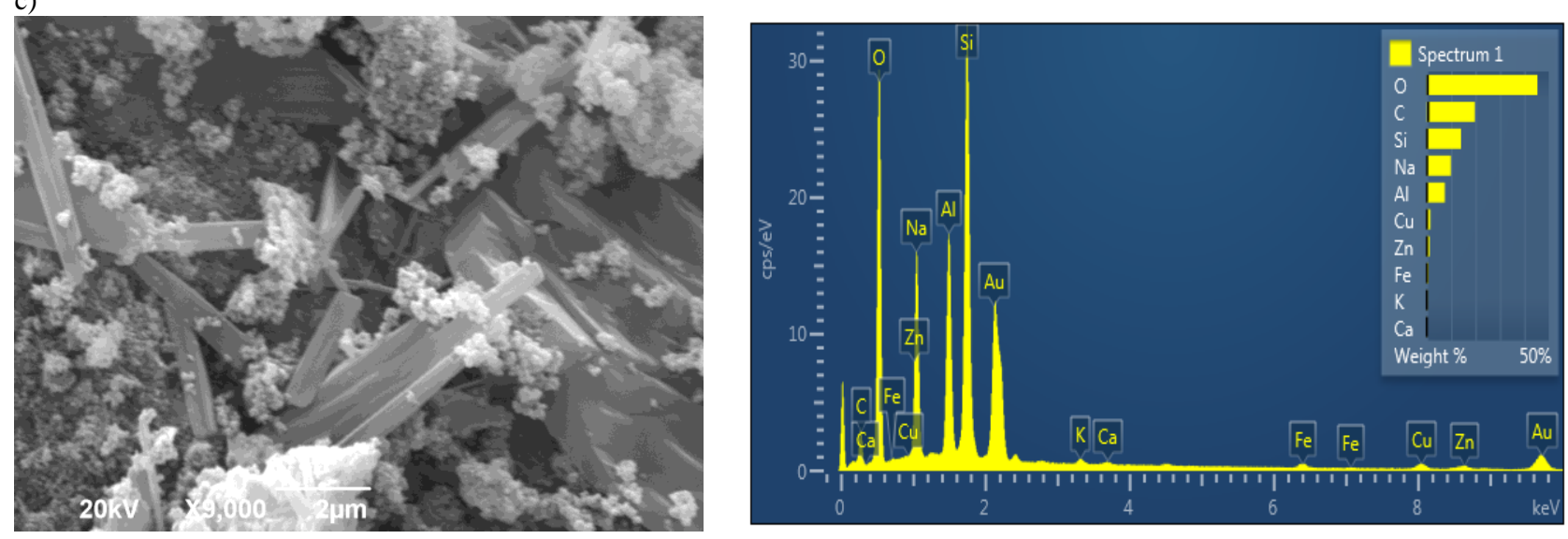

d)

Fig. 9. SEM micrographs of geopolymer samples and its EDS spectra: a) $2 M G$, b) $4 M G$, c) $6 M G$ and d) $8 M G$ 
Figures $9 \mathrm{a}, 9 \mathrm{~b}$ and $9 \mathrm{c}$ show separate phases of stick-shaped crystallites as well as agglomerated particles of geopolymer gel structure. 8MG (Fig. 9d) shows a microstructure consisting of dense plates formed by geopolymerization of metakaolin with a group of crystalline rods. These crystalline forms merge in some places, which can be attributed to the recrystallization of some kind of silicon or $\mathrm{Al}-\mathrm{OH}$ form [30]. However, the geopolymer dense plates that are observed indicate that these are the strongest constituents. The presence of higher amounts of hydroxyl ions will favor the dissociation of different silicate and aluminate species, subsequently promoting further polymerization between them, which means that geopolymerisation is accelerated in a highly concentrated alkaline environment [35]. The elemental composition of the area presented in the EDS analysis was found to be dominated by silicon, aluminum, and sodium. $\mathrm{Ca}, \mathrm{Cu}, \mathrm{K}, \mathrm{Fe}, \mathrm{Zn}$ are present in smaller percentages. Unlike previous research [13], we noticed that changes in the ratio of the solid and liquid phases lead to very fine changes in the structure. Such changes are reflected in the mineral and microstructural properties. The results obtained also indicate that the formulation of the alkaline activator is very important and that it plays a key role in the geopolymerization process. Therefore, it is necessary to examine the influence of thermodynamic parameters of the alkaline activator on the properties of geopolymers in real conditions. The introduction of new instrumental methods would give us more information about possible connections (i.e., structural units of inorganic polymersgeopolymers). The XPS analysis of geopolymer samples shown in the previous research [40] allows us to discuss more about the contributions of individual bonding.

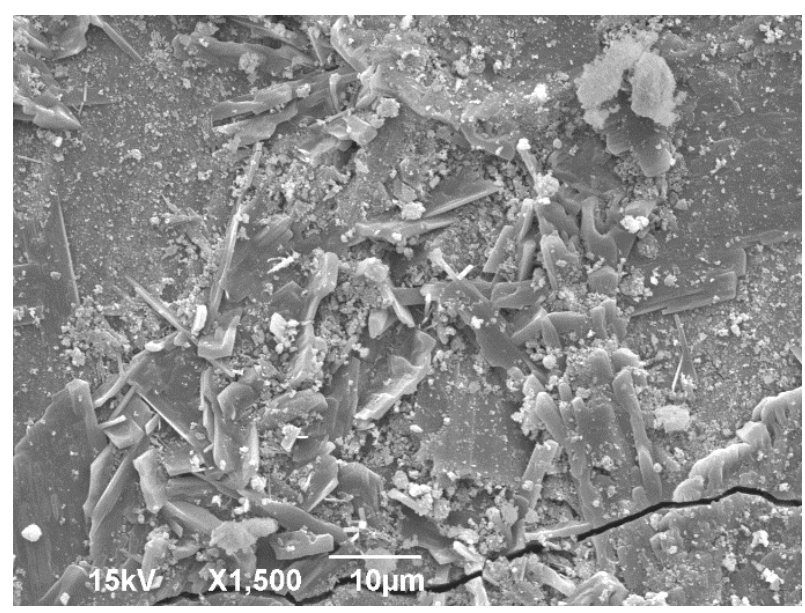

Fig. 10. SEM micrographs of plate of $8 \mathrm{MG}$ geopolymer sample
In contrast to the powder samples, we illustratively present the $8 \mathrm{MG}$ SEM micrograph as a plate obtained before grinding (Fig. 10).

A glass rod irregularly arranged in different directions can be seen through the surface of the cast sample. In addition, small irregularly shaped particles smaller than $10 \mu \mathrm{m}$ can be seen on the surface, which represent the already mentioned impurities.

\section{CONCLUSION}

Various types of solutions can be used as activators in the synthesis of geopolymers. The chemical and physical properties of each activator will play a role in determining the properties and values of the geopolymers synthesized by them. The use of $\mathrm{NaOH}$ as an part of activator in geopolymer synthesis and of metakaolin as precursor is very widespread due to their low cost, wide availability and low viscosity. The viscosity of sodium silicate solutions decreases markedly with increasing temperature. The system with the highest concentration of $\mathrm{NaOH}$ shows significantly higher viscosity compared to the other three analyzed systems, especially at lower temperatures. These systems have been shown to behave like conventional liquid systems - they decrease with increasing temperature due to thermal expansion of the liquid. The obtained results related to thermodynamic parameters of alkaline activators are the basis for further research on the rheology of geopolymers as inorganic polymers. The inorganic polymers were obtained by the alkaline activation of calcined kaolin-metakaolin, which is a material of very complex composition and structure. XRD, FTIR, Raman spectroscopy and SEM analysis were used to investigate the structure of the geopolymer samples. The present study contributes to a broader explanation of the mechanisms which occur during the geopolymerization process. EDS analysis showed that silicon is the element with the highest content in all samples, which is another indicator of the crystalline phase. Our research also pointed out that Raman spectroscopy and FTIR spectroscopy are suitable methods to detect the polymerization. All three methods confirmed the existence of crystalline phases, where the minerals quartz, kaolinite, and muscovite predominated. Namely, our data confirm the high sensitivity of Raman spectroscopy in identifying the main hydrated and anhydrated phases. FTIR results correlated with Raman analysis confirmed changes in the phonon spectrum due to the polymerization process. The 
obtained results can be useful for further research, especially for predicting the behavior of a system.

Acknowledgement. This work was supported by the Ministry of Education, Science and Technological Development of Republic of Serbia.

Conflict of Interest: The authors declare that they have no conflict of interest.

\section{REFERENCES}

[1] J. Davidovits, Geopolymers. Journal of Thermal Analysis, 37 (8), 1633-1656 (1991).

DOI: https://doi.org/10.1007/BF01912193

[2] J. Davidovits, Geopolymer chemistry and sustainable development, Conference at: Saint-Quentin, France. Institut Géopolymère / Geopolymer Institute, Volume: Session 1, 9-17 (2005).

[3] J. Davidovits, Geopolymers and geopolymeric new materials, Journal of Thermal Analysis, 35 (2), 429-441 (1989).

[4] E. Gartner, Industrially interesting approaches to "low$\mathrm{CO}_{2} "$ cements, Cem. Concr. Res., 34, 1489-1498 (2004). DOI: 10.1016/j.cemconres.2004.01.021

[5] H. Xu, J. S. J. Van Deventer, The geopolymerisation of alumino-silicate minerals', International Journal of Mineral Processing, 59, 247 (2000).

DOI: doi.org/10.1016/S0301-7516(99)00074-5

[6] J. Davidovits, Geopolymers Chemistry and Applications, Institut Geopolymere: Saint-Quentin, France, Edition: 2nd (2008).

[7] S. Nenadović, G. Musci, Lj. Kljajević, M. Mirković, M. Nenadović, F. Kristaly, I. Vukanac, Physicochemical, minerological and radiological properties of red mud samples as secondary raw materials, Nuclear Technology and Radioactivity Protection, 32 (3), 261-266 (2017). DOI:10.2298/NTRP1703261N

[8] W. M. Kriven, J. L. Bell, M. Gordon, Microstructure and microchemistry of fully-reacted geopolymers and geopolymer matrix composites, Ceram. Trans., 153, 227-250 (2004).

[9] E. Landi, V. Medri, E. Papa, J. Dedecek, P. Klein, P. Benito, A. Vaccari, Alkali bonded ceramics with hierarchical tailored porosity, Appl. Clay Sci., 73, 56-64 (2013). DOI: 10.1016/j.clay.2012.09.027

[10] O. Bortnovsky, J. Dědeček, Z. Tvarůžková, Z. Sobalík, J. Šubrt, Metal ions as probes for characterization of geopolymer materials, J. Am. Ceram. Soc., 91, 3052-3057 (2008).

DOI: https://doi.org/10.1111/j.1551-2916.2008.02577.x

[11] J. L. Provis, J. S. J. van Deventer, $1^{\text {st }}$ edition Geopolymers: Structures, Processing, Properties and Industrial Applications, Chapter 4: Activating solution chemistry for geopolymers, Woodhead Publishing, 2009.

[12] B. Fabbri, S. Gualtieri, C. Leonardi, Modifications induced by the thermal treatment of kaolin and determination ofreactivity of metakaolin, Applied Clay Science 73, (2013). DOI: https://doi.org/10.1016/j.clay.2012.09.019
[13] N. Mladenović, Lj. Kljajević, S. Nenadović, M. Ivanović, B. Čalija, J. Gulicovski, K. Trivunac, The applications of new inorganic polymer for adsorption cadmium from waste water, Journal of Inorganic and Organometallic Polymers and Materials, 554 (2020). DOI: 10.1007/s10904-019-01215-y

[14] K. Trivunac, Lj. Kljajević, S. Nenadović, J. Gulicovski, M. Mirković, B. Babić, S. Stevanović, Microstructural characterization and adsorption properties of alkaliactivated materials based on metakaolin, Science of Sintering, 48 (2), 209-220 (2016). DOI: $10.2298 / \mathrm{SOS} 1602209 \mathrm{~T}$

[15] X. Yang, W. Zhu, Q. Yang, The viscosity properties of sodium silicate solutions, Journal of Solution Chemistry, 37, 73-83 (2008). DOI: 10.1007/s10953-007-9214-6

[16] J. G. Vail, Soluble Silicates: Their Properties and Uses, New York, Reinhold (1952).

[17] M. Singha, L. Singh, Vibrational spectroscopic study of muscovite and biotite layered phyllosilicates, Indian Journal of Pure and Applied Physics, 54, 116-122 (2016).

[18] L. Zhang, F. Zhang, M. Liu, X. Hu, Novel sustainable geopolymer based syntactic foams: An eco-friendly alternative to polymer based syntactic foams, Chemical Engineering Journal, 313, 74-82 (2017). DOI: $10.1016 /$ j.cej.2016.12.046

[19] E. Izci, Structural and dielectric properties of acid activated metakaolinite and kaolinite, 11th GeoRaman International Conference, 2014.

https://www.hou.usra.edu/meetings/georaman2014/pdf/5 097.pdf

[20] H. Aguiar, J. Serra, P. González, B. León, Structural study of sol-gel silicate glasses by IR and Raman spectroscopies, Journal of Non-Crystalline Solids, 355, 475480 (2009). DOI: 10.1016/j.jnoncrysol.2009.01.010

[21] S. Y. R López, J. S. Rodríguez, Microstructural characterization of sanitary ware by infrared and Raman spectroscopy, the role of vitreous matrix on properties, Journal of Ceramic Processing Research, Vol. 16, No. 1, 162-168 (2015).

[22] T. Kosor, B. Nakic-Alfirević, S. Svilović, Geopolymer depolymerization index, Vibrational Spectroscopy, 86, 143-148 (2016). DOI:10.1016/j.vibspec.2016.07.004

[23] L. Vidal, A. Gharzouni, E. J. Joussein, M. Colas, J. Cornette, J. Absi, S. Rossignol, Determination of the polymerization degree of various alkaline solutions: Raman investigation, Journal of Sol-Gel Science and Technology, Springer Verlag, 83 (1), 1-11 (2017). DOI: $10.1007 / \mathrm{s} 10971-017-4394-\mathrm{z}$.

[24] L. Vidal, E. Joussein, M. Colas, J. Cornette, J. Sanz, I. Sobrados, J. L. Gelet, J. Absi, S. Rossignol, Controlling the reactivity of silicate solutions: A FTIR, Raman and NMR study, Colloids and Surfaces A: Physicochem. Eng. Aspects, 503, 101-109 (2016). DOI: https://doi.org/10.1016/j.colsurfa.2016.05.039

[25] B. O. Mysen, D. Virgo, I. Kushiro, The structural role of aluminum in silicate melts - a Raman spectroscopic study at 1 atmosphere, American Mineralogist, 66, 678701 (1981). 
[26] Y. Yu, G. Xiong, C. Li, F. S. Xiao, Characterisation of aluminosilicate zeolites by UV Raman spectroscopy, Microporous and Mesoporous Materials, 46, 23-34 (2001).

[27] K. Yadav, P. Singh, A review of the structures of oxide glasses by Raman spectroscopy, RSC Adv. 5 (2015) 67583-67609.

DOI: https://doi.org/10.1039/C5RA13043C

[28] P. K. Dutta, D. C. Shieh, Raman spectral study of the composition of basic silicate solutions, Applied Spectroscopy, 39 (2), 343-346 (1985).

[29] S. Rossano, B. Mysen, Raman spectroscopy of silicate glasses and melts in geological systems, EMU Notes in Mineralogy, Vol. 12, Chapter 9, 319-364 (2012).

[30] C. Karlsson, E. Zanghellini, J. Swenson, B. Roling, D. T. Bowron, L. Börjesson, Structure of mixed alkali/alkaline-earth silicate glasses from neutron diffraction and vibrational spectroscopy, Phys Rev B 2005, 72:064206. DOI: 10.1103/PhysRevB.72.064206

[31] J. L. Provis, C. A. Rees, Geopolymer synthesis kinetics. In: Provis, J. L. and Van Deventer, J. S. J. (Eds.): Geopolymers: Structures, Processing, Properties and Industrial Applications, Woodhead Publishing, Abingdon UK, 2009, pp. 118-136.

[32] P. Innocenzi, Infrared spectroscopy of silica sol-gel films: A spectra- microstructure overview, J. Non-Cryst. Solids, 316, 309-319 (2003). DOI: https://doi.org/10.1016/S0022-3093(02)01637-X

[33] A. Fernandez-Jimenez, A. Palomo, Mid-infrared spectroscopic studies of alkaline activated fly ash structure. Micropor Mesopor Mater, 86, 207-214, (2005). DOI:10.1016/j.micromeso.2005.05.057
[34] M. Alkan, C. Hopa, Z. Yilmaz, H. Guler, The effect of alkali concentration and solid/liquid ratio on the hydrothermal synthesis of zeolite NaA from natural kaolinite, Microporous Mesoporous Materials, 86, 176-184 (2005).

[35] X. Zhao, C. Liu, L. Wanga, L. Zuo, Q. Zhu, W. Ma, Physical and mechanical properties and micro characteristics of fly ash based geopolymers incorporating soda residue, Cement and Concrete Composites, 98, 125-136 (2019).

[36] N. Lee, H. R. Khalid, H. Lee, Synthesis of mesoporous geopolymers containing zeolite phases by a hydrothermal treatment, Microporous Mesoporous Mater., 229, 22-30 (2016).

DOI: https://doi.org/10.1016/j.micromeso.2016.04.016

[37] J. L. Provis, G. C. Lukey, J. S. Van Deventer, Do geopolymers actually contain nanocrystalline zeolites? A reexamination of existing results, Chem. Mater., 17, 3075-3085 (2005).

DOI: https://doi.org/10.1021/cm050230i

[38] A. Palomo, F. Glasser, Chemically-bonded cementitious materials based on metakaolin, British Ceramic Transactions, 91, 107-112 (1992).

[39] S. Alonso, A. Palomo, Calorimetric study of alkaline activation of calcium hydroxide-metakaolin solid mixtures, Cement and Concrete Research, 31, 25-30 (2001). DOI: $10.1016 / \mathrm{S} 0008-8846(00) 00435-\mathrm{X}$

[40] Lj. Kljajević, S. Nenadović, M. Nenadović, N. Bundaleski, B. Todorović, V. Pavlović, Ž. Rakočević, Structural and chemical properties of thermally treated geopolymer samples, Ceramics International, 43, 67006708 (2017). DOI: 10.1016/j.ceramint.2017.02.066 
